Print ISSN: 2288-4637 / Online ISSN 2288-4645

doi:10.13106/jafeb.2020.vol7.no11.541

\title{
Migration and Economic Inequality in Indonesia: Longitudinal Data Analysis
}

\author{
Imamudin YULIADI ${ }^{1}$, Sigit Satria RAHARJA ${ }^{2}$
}

Received: August 01, 2020 Revised: September 28, 2020 Accepted: October 05, 2020

\begin{abstract}
This study aimed to explain the factors that influenced an individual's decision to migrate. The method of analysis in this study was the estimation of the probit regression model with data from the Indonesian Family Life Survey (IFLS-5), which covered 30,000 individuals from 13 provinces in Indonesia. Data from IFLS-5 were longitudinal data, meaning that the study was looking for data consistently to get reliable data from respondents. The research variables to determine the individual's decision to migrate were education level, income level, employment status, marital status, land ownership status, health quality, gender, residence status, and poverty status. Individual decision to migrate as a dependent variable was placed as a dummy variable. The results showed that the level of education, income level, employment status, marital status, land ownership status, health quality, and poverty status significantly influenced an individual's decision to migrate. Meanwhile, gender and residence status did not significantly affect an individual's decision to migrate. This research recommends that it is necessary to pursue a policy of economic equality between regions because economic factors are the main trigger for an individual's decision to migrate. Policies to overcome economic disparities among regions will reduce the individual's decision to migrate.
\end{abstract}

Keywords: Migration, Economic Inequality, Individual Decisions

JEL Classification Code: D63, D91, R23, O15

\section{Introduction}

In general, the phenomenon of migration is based on economic motives, specifically to improve economic conditions by looking for places that can provide jobs and income better than the place of origin (Martin \& Zürcher, 2008; Mayda, 2010; Purnomo, 2009; Kousar et al., 2019; H. T. T. Nguyen, Nguyen, \& Nguyen, 2020; T. T. Nguyen, 2020). Migration also has an impact on the flow of funds (remittance) to the family in the place of origin. Migrants contribute to their families and communities in their country of origin by sending money home. (Adams

${ }^{1}$ First Author and Corresponding Author. Associate Professor, Business and Economic Faculty, Universitas Muhammadiyah Yogyakarta, Indonesia [Postal Address: Jl. Brawijaya, Tamantirto, Kec. Kasihan, Yogyakarta, 55183, Indonesia] Email: imamudin2006@yahoo.co.id 'Lecturer, Business and Economic Faculty, Universitas Muhammadiyah Yogyakarta, Indonesia

(c) Copyright: The Author(s)

This is an Open Access article distributed under the terms of the Creative Commons Attribution Non-Commercial License (https://creativecommons.org/licenses/by-nc/4.0/) which permits unrestricted non-commercial use, distribution, and reproduction in any medium, provided the original work is properly cited.
$\&$ Page, 2005). In many cases, migration improves the quality of well-being, health, and education of migrants (Lu, 2010; Saptanto, Lindawati, \& Zulham, 2011; Vujicic et al., 2004).

From an economic perspective, migration arises because of a gap in labor wages between the area of origin and the destination such that it encourages the movement of workers to places that provide higher wages (Kerr \& Kerr, 2011). However, migration often creates social problems, including competition between the local residents and migrants. The welfare provision policy is often given to migrants because many are unemployed, and the welfare level is lower than that of most local people (Adema \& Ladaique, 2009; Barrett et al., 2013; Lumpe, 2007). Migration in other aspects also provides a positive climate for the destination because it creates competition, thereby encouraging increased productivity of the community (Devlin et al., 2014). This research, therefore, reveals individual decisions and driving factors in migrating in Indonesia. Individual decision factors are gender, marital status, and educational status. Whereas, driving factors are income, employment status, residence status, employment status, and health quality. The combination of the variables of individual decision factors and the drivers of migration 
in Indonesia is an interesting part of this study compared to previous research on migration in developing countries.

Hanley et al. (2019) have researched the health aspects of female migrants and household safety as research variables on migration but did not include aspects of marital status, income level, and education status. Wood \& Kallestrup (2018) and Polillo et al. (2018) studies revealed employment status and the quality of health as considerations for migrating. Gender and employment status are also interesting variables to be analyzed in explaining individual considerations to migrate as new information in analyzing migration compared to previous studies (Hanley et al., 2019; Hollis, 2019; Maleku, Kim, \& Lee, 2019). The studies revealed that gender differences affected individual decisions in migrating, whether there were specific considerations between men and women in determining the decision to migrate or not. Likewise, employment status becomes an essential variable in determining individual decisions in migrating because it involves economic considerations (Vitale \& Doherty, 2018). Health aspects also become important from research on individual decisions in migrating, each of which is rarely revealed by previous studies (Vitale \& Doherty, 2018). The research of Hollis (2019) used aspects of the psychosocial experience of immigrants in the UK as research variables. However, in that study, the aspects of land ownership and health quality were not included as determinants that influenced an individual's decision to migrate.

On the other hand, individuals and families decide to migrate because there are better hopes for the future in new areas. Also, it is because of new business opportunities, abundant economic resources, the emergence of new job opportunities, and the existence of life guarantees that are more in line with individual and family expectations (Catalbas \& Yarar, 2015). The status of residence also influenced the motive for a person to migrate. It is a new factor in explaining the phenomenon of immigration in developing countries. Polillo et al. (2018) have researched migration due to consideration of residence, but his research did not include aspects of income, education level, and land ownership status.

The phenomenon is also influenced by other factors, namely due to forced, induced, and spontaneous factors. The forced factor becomes a trigger to migrate because there is no other choice but to migrate, for example, in the case of someone who has moved away due to social conflicts that threaten life and personal and family safety. Induced factor (induced) arises because of the attachment of individuals and families to the environment and community. When the community and the environment migrate, it will affect an individual's decision to move, for example, the child's decision to move when his parents move. While the independence factor (spontaneous) arises because of objective considerations from someone who rationally decides to migrate because he wants to get better living conditions. For example, the decision of a scholar to migrate because of the demands of a workplace that promises better compensation (Tombe \& Zhu, 2019). Therefore, an essential aspect of this research is how and what factors influence individual decisions to migrate in Indonesia.

\section{Literature Review}

Research on migration has been carried out by many economic and social experts with various approaches. Gray and Bilsborrow (2013) revealed that the factors that influence migration are fertility or birth, death or mortality, population migration, social mobility, and marriage. Fertility factor triggers migration because population growth through birth will lead to new needs concerning shelter, sources of livelihood, education, etc. which are not necessarily available at their original place. The aspect of mortality can also be a driver of migration due to death, especially in large numbers, which will cause concern so that it encourages motivation to move to a place that better guarantees the future. Likewise, social mobility and marriage factors can be a trigger of mobility with increasingly varied motives (Burakov, 2017; Yalaz \& Zapata-Barrero, 2018).

Population migration is the implication of population issues, which is characterized by several problems, namely (1) High population growth rate, (2) Uneven population distribution, (3) Demographic pyramid dominated by unproductive and aged population such that the dependency ratio is quite high, (4) The number of the labor force is high, and the number of job opportunities is limited such that it causes unemployment, (5) Low health quality index that affects the quality of human resources (HR) and economic productivity, (6) Economic disparities between regions and between groups that are still quite high which raises the potential for high social conflict (Fasani, Frattini, \& Minale, 2017).

The migration desire is a social phenomenon that engulfs any country with different motivations. Based on records, $30 \%$ of the population in the world move to get a better life. Migration arises because of economic differences and flows from one region to another with more significant economic opportunities, such as more jobs available and higherincome/wages.

The World Bank (2016) saw a critical problem in Indonesia regarding the uneven distribution of the population. There was a tendency that the demand for skilled labor was high enough in urban areas to support the needs in the service sector. Uneven employment availability factors increase wage inequality. Unequal population distribution and also uneven employment distribution encourage higher wage inequality between regions and between groups. In general, people will tend to look for a better life by migrating to areas that can increase income and welfare (Mayda, 2010).

The primary motive for people to move from their areas (rural) to urban areas is economic motives. The motive developed because of the economic imbalances between 
regions (Hossain, 2001). The conditions most felt by individuals become rational considerations, where they migrate to the city in the hope of finding better work and higher income than that available in the village. The city is a destination to try one's luck because it promises more prospects and opportunities than a village (Stańczyk-Mazanek, Stępniak, \& Kępa, 2019).

\section{Research Methods}

Research on migration in Indonesia was included in the explanatory study, where data obtained were from survey data on aspects of Indonesian household life (SAKERTI) or Indonesian Family Life Survey (IFLS). SAKERTI is an individual longitudinal comprehensive survey taken at the household level and is the first longitudinal survey in Indonesia. The sample drawn from this data was households for which data was still available in 2015.

The unit of analysis in this study was households, both men and women aged 15 years and over, at the time of enumeration recorded at IFLS in 2015. Besides, the variables were related to age, gender, marital status, education level, income, employment status, residence status, agricultural land ownership, poverty status, and health quality.

Data collection methods used in this study are secondary data, employing survey data on aspects of Indonesian household life (SAKERTI) or Indonesian Family Life Survey (IFLS). Data processing was carried out using the Stata application. In the implementation of the IFLS, the handbook questions (IFLS Household survey questionnaires) comprised:

BookT: Tracking book; BookK: Control book and household roster; Book1: Expenditures and knowledge of Health Facilities; Book2: Household Economy; Book3A: Adult information (part1); Book3B: Adult information (part2); Book4: Ever married woman information; Book5: Child information; Book Proxy: Adult information by proxy; BookUS1: Health Assessment; BookUS2: Health Observation/evaluation; BookEK: Cognitive Assessment.

The equation of the probit regression model, which was used in this study, is as follows:

$$
\begin{aligned}
\mathrm{y} & =\alpha+\beta \mathrm{X} 1+\beta \mathrm{X} 2+\beta \mathrm{X} 3+\beta \mathrm{X} 4+\beta \mathrm{X} 5+\beta \mathrm{X} 6+\beta \mathrm{X} 7 \\
& +\beta \mathrm{X} 8+\beta \mathrm{X} 9+\mathrm{e}
\end{aligned}
$$

Where:

$\mathrm{y}=$ The probability of the respondent migrating; $\mathrm{X} 1=$ Gender; $\mathrm{X} 2=$ Marital status; $\mathrm{X} 3=$ Level of education; $\mathrm{X} 4=$ Income; $\mathrm{X} 5$ = Employment status; $\mathrm{X} 6=$ Status of residence; $\mathrm{X} 7=$ Agricultural Land Ownership; X8 = Poverty Status; X9 = Health Quality; $\alpha=$ A constant; $\beta=$ Coefficient; $\mathrm{e}=$ Error

To get the standard value of the proportional regression coefficient, each free variable would be tested using statistical tests. The statistical test determines whether the independent variables contained in the model have a significant relationship with the dependent variable. Statistical tests are useful to see the significance of each control variable in explaining the dependent variables on the model, using the F-test and t-test.

\subsection{Data and Facts of Migration in Indonesia}

Migration in Indonesia is a social phenomenon that has occurred for a long time. Even in history, it can be seen that Indonesian society was built through the migration of people from the Central Asian, Middle Eastern, South Asian, and European regions. There are two patterns of migration in society. The first one is international migration, in which Indonesians go abroad to find better jobs and income. The migration of workers abroad, such as to the Middle East, Hong Kong, Taiwan, Japan, Malaysia, Japan, and Singapore is based on getting better wages. In this case, the transfer of funds (remittance) from abroad to the place of origin can improve the economic condition of the family left behind, so that, they can buy land, repair houses, have the capital to open a business, etc. The second migration pattern is internal migration, where there is an inter-island or inter-regional population movement in Indonesia to improve the economic condition of the family. In general, the western region of Indonesia is more advanced than the eastern part of Indonesia, hence migration occurs from the eastern region to the western region, especially to the island of Java. Migration from outside the island of Java to the island of Java is because it is the center of government and economic activity. Java provides more extensive opportunities for migrants to get jobs with higher income levels compared to the place of origin. Java Island, especially the area of Jakarta, Bogor, Depok, Tangerang, and Bekasi (Jabodetabek), are the centers of business and commerce, making them the mainstay of job seekers from other regions.

The destinations of migrants alongside Java are Sumatra, Kalimantan, Sulawesi, and Bali, who require labor in the fields of mining, plantations, hospitality, industry, services, and trade. Kalimantan and Sumatra operate many foreign oil companies as well as palm oil plantation companies. Whereas Bali is known as a mainstay tourist destination visited by many tourists from home and abroad. The following table explains the migration phenomenon in Indonesia:

Table 1 illustrates how inter-island migration flows in Indonesia. Java, as the economic center of Indonesia, is a mainstay of job seekers. Migration data in 2010 showed that the number of the Sumatran population who went to Java was 0.3 million, or from the majority, $87.67 \%$ headed to Java. Population migration from Kalimantan to Java was 0.1 million, and around $62.46 \%$ migrated to Java. The number of migrants from Sulawesi was 0.1 million, and around $20.76 \%$ migrated to Java. Whereas, the number of migrants from other islands were 0.1 million inhabitants, and around $20.76 \%$ migrated to big cities in Java. 
Table 1: Lifetime In Migration, Lifetime Out Migration, and Lifetime Net Migration by Province and Sex

\begin{tabular}{|c|c|c|c|c|c|c|c|c|c|}
\hline \multirow[b]{2}{*}{ Province } & \multicolumn{3}{|c|}{ In Migration } & \multicolumn{3}{|c|}{ Out Migration } & \multicolumn{3}{|c|}{ Net Migration } \\
\hline & Male & Female & $\begin{array}{c}\text { Male+ } \\
\text { Female }\end{array}$ & Male & Female & $\begin{array}{l}\text { Male+ } \\
\text { Female }\end{array}$ & Male & Female & $\begin{array}{l}\text { Male+ } \\
\text { Female }\end{array}$ \\
\hline (1) & (2) & (3) & (4) & (5) & (6) & (7) & (8) & (9) & (10) \\
\hline Aceh & 105124 & 104691 & 209815 & 134943 & 122793 & 257736 & -29819 & -18102 & -47921 \\
\hline Sumatera Utara & 260598 & 259245 & 519843 & 1120740 & 1086332 & 2207072 & -860142 & -827087 & -1687229 \\
\hline Sumatera Barat & 187462 & 170661 & 358123 & 593428 & 555502 & 1148930 & -405966 & -384841 & -790807 \\
\hline Riau & 985528 & 895551 & 1881079 & 164317 & 155241 & 319558 & 821211 & 740310 & 1561521 \\
\hline Jambi & 375108 & 335320 & 710428 & 108266 & 88997 & 197263 & 266842 & 246323 & 513165 \\
\hline Sumatera Selatan & 509731 & 456329 & 966060 & 369883 & 367702 & 737585 & 139848 & 88627 & 228475 \\
\hline Bengkulu & 177142 & 159899 & 337041 & 55892 & 54945 & 110837 & 121250 & 104954 & 226204 \\
\hline Lampung & 709161 & 653226 & 1362387 & 350199 & 390655 & 740854 & 358962 & 262571 & 621533 \\
\hline $\begin{array}{l}\text { Kep.Bangka } \\
\text { Belitung }\end{array}$ & 104296 & 88433 & 192729 & 50002 & 56123 & 106125 & 54294 & 32310 & 86604 \\
\hline Kepulauan Riau & 454436 & 426599 & 881035 & 51062 & 48913 & 99975 & 403374 & 377686 & 781060 \\
\hline DKI Jakarta & 1781050 & 1866278 & 3647328 & 1389667 & 1311478 & 2701145 & 391383 & 554800 & 946183 \\
\hline Jawa Barat & 2594406 & 2367135 & 4961541 & 1178150 & 1169978 & 2348128 & 1416256 & 1197157 & 2613413 \\
\hline Jawa Tengah & 506597 & 509018 & 1015615 & 3385299 & 3166459 & 6551768 & -2878702 & -2657451 & -5536153 \\
\hline DI Yogyakarta & 271866 & 300082 & 571948 & 471673 & 440734 & 912407 & -199807 & -140652 & -340459 \\
\hline Jawa Timur & 452540 & 471612 & 924152 & 2044584 & 1777108 & 3821692 & -1592044 & -1305496 & -2897540 \\
\hline Banten & 1290613 & 1200976 & 2491589 & 288561 & 291229 & 579790 & 1002052 & 909747 & 1911799 \\
\hline Bali & 220613 & 207898 & 428511 & 138126 & 126576 & 264702 & 82487 & 81322 & 163809 \\
\hline $\begin{array}{l}\text { Nusa Tenggara } \\
\text { Barat }\end{array}$ & 58752 & 63076 & 121828 & 117949 & 91320 & 209269 & - 59197 & -28244 & -87441 \\
\hline $\begin{array}{l}\text { Nusa Tenggara } \\
\text { Timur }\end{array}$ & 83559 & 93049 & 176608 & 158082 & 95630 & 253712 & - 74523 & -2581 & -77104 \\
\hline $\begin{array}{l}\text { Kalimantan } \\
\text { Barat }\end{array}$ & 167052 & 126940 & 293992 & 91202 & 94722 & 185924 & 75850 & 32218 & 108068 \\
\hline KalimantanTengah & 288570 & 238903 & 527473 & 47145 & 58453 & 105598 & 241425 & 180450 & 421875 \\
\hline $\begin{array}{l}\text { Kalimantan } \\
\text { Selatan }\end{array}$ & 272173 & 237794 & 509967 & 151127 & 151809 & 302936 & 121046 & 85985 & 207031 \\
\hline $\begin{array}{l}\text { Kalimantan } \\
\text { Timur }\end{array}$ & 602179 & 517838 & 1120017 & 73148 & 71379 & 144527 & 529031 & 446459 & 975490 \\
\hline $\begin{array}{l}\text { Kalimantan } \\
\text { Utara }\end{array}$ & 105986 & 83410 & 189396 & 20683 & 22531 & 43214 & 85303 & 60876 & 146179 \\
\hline
\end{tabular}


Table 1: Continued

\begin{tabular}{|l|c|c|c|c|c|c|c|c|c|}
\hline Sulawesi Utara & 99707 & 88429 & 188136 & 96665 & 98879 & 195544 & 3042 & -10450 & -7408 \\
\hline Sulawesi Tengah & 244624 & 220990 & 465614 & 59591 & 62337 & 121928 & 185033 & 158653 & 343686 \\
\hline Sulawesi Selatan & 182437 & 163731 & 346168 & 759855 & 653833 & 1415688 & -577418 & -492102 & -1069520 \\
\hline Sulawesi Tenggara & 231316 & 212286 & 443602 & 99639 & 92228 & 191917 & 131627 & 120058 & 251685 \\
\hline Gorontalo & 32417 & 32031 & 64448 & 54018 & 49874 & 103892 & -21601 & -17843 & -39444 \\
\hline Sulawesi Barat & 89826 & 85457 & 175283 & 56301 & 52342 & 108643 & 33525 & 33115 & 66640 \\
\hline Maluku & 70795 & 63705 & 134500 & 114532 & 100546 & 215028 & -43737 & -36841 & -80578 \\
\hline Maluku Utara & 56734 & 50185 & 106920 & 31160 & 30811 & 61971 & 25574 & 19375 & 44949 \\
\hline Papua Barat & 147836 & 124315 & 272151 & 24517 & 27242 & 51759 & 123319 & 97073 & 220392 \\
\hline Papua & 271833 & 219823 & 491656 & 48315 & 40946 & 89261 & 223518 & 178877 & 402395 \\
\hline
\end{tabular}

Source: Statistics Indonesia, Migration in Indonesia

\section{Results and Discussion}

This study employed probit regression, which aimed to find out how significant was the probability of a decision of the population in IFLS households in 2014 to migrate. The results of the estimated probit model of research on migration determinants in Indonesia can be seen in the following Table 2:

From the probit regression in Table 2, the results showed that the probability of an individual making a migration decision was influenced by variables of marital status, education level, income, and employment status, ownership of agricultural land, poverty status, and health quality. Meanwhile, gender and residence status variables did not influence individuals to make migration decisions. The independent variable that influenced an individual's decision to migrate had a significant level of 5\%. From the estimated table above, the equation model can be concluded, as follows:

\begin{tabular}{|c|c|c|c|c|c|c|c|}
\hline \multirow[b]{2}{*}{$p$-value } & \multicolumn{7}{|c|}{$\begin{array}{l}\text { Migration }=-1.614+0.025 \text { sex }+0.137 \text { marital } \\
+0.248 \text { education }\end{array}$} \\
\hline & & \multicolumn{2}{|c|}{$(0.368)$} & \multicolumn{2}{|c|}{$(0.000)$} & \multicolumn{2}{|c|}{$(0.000)$} \\
\hline & \multicolumn{7}{|c|}{$\begin{array}{l}+0.195 \text { income }+0.084 j o b+0.019 \text { home }+ \\
0.240 \text { land }+0.162 \text { poor }\end{array}$} \\
\hline \multirow[t]{2}{*}{$p$-value } & \multicolumn{2}{|c|}{$(0.000) \quad(0.021)$} & \multicolumn{2}{|c|}{$(0.506)$} & \multicolumn{2}{|c|}{$(0.000)$} & $(0.000)$ \\
\hline & \multicolumn{6}{|c|}{+0.056 health } & \\
\hline$p$-value & \multicolumn{7}{|l|}{$(0.008)$} \\
\hline $\begin{array}{l}\text { Prob LR } \\
\text { Statistic }\end{array}$ & \multicolumn{7}{|l|}{$=0.0000$} \\
\hline
\end{tabular}

Table 2: Probit Regression Results for Migration Decisions

\begin{tabular}{|l|c|c|}
\hline Variable & Coefficient & Standard error \\
\hline Gender & $.0255051^{* *}$ & .0283085 \\
\hline Marital status & $.1377016^{*}$ & .032735 \\
\hline Level of education & $.2487966^{*}$ & .0124348 \\
\hline Income & $.1955601^{*}$ & .0285594 \\
\hline Employment status & $.0847513^{*}$ & .036786 \\
\hline Status of residence & $.0199621^{* *}$ & .0300342 \\
\hline $\begin{array}{l}\text { Agricultural Land } \\
\text { Ownership }\end{array}$ & $.2409374^{*}$ & .0318739 \\
\hline Poverty Status & $.1624231^{*}$ & .0315989 \\
\hline Health Quality & $.0562374^{*}$ & .0210465 \\
\hline Pseudo R2 0.0600 & & \\
\hline $\begin{array}{l}\text { Prob LR Statistic } \\
\text { 0.0000 }\end{array}$ & & \\
\hline
\end{tabular}

* Significant at $\alpha=5 \%$; ** Not Significant $\alpha=5 \%$

b1 = With a significance level of $5 \%$, there was not enough evidence that gender influenced individual migration decisions in 2014 IFLS households.

b2 $=$ With a significance level of $5 \%$, marital status significantly and positively impacted the probability of individuals to migrate with a p-value of 0,000 .

b3 = With a significance level of $5 \%$, the level of education significantly and positively affected the probability of individuals to migrate with a p-value of 0,000 . 
b4 $=$ With a significance level of $5 \%$, income had a significant and positive effect on the probability of individuals to migrate with a p-value of 0,000 .

b5 $=$ With a significance level of $5 \%$, employment status had a significant and positive effect on the probability of individuals to migrate with a p-value of 0.021 .

b6 $=$ With a significance level of $5 \%$, there was not enough evidence that residence status influenced individual migration decisions in 2014 IFLS households.

b7 $=$ With a significance level of $5 \%$, agricultural land ownership had a significant and positive impact on the probability of individuals to migrate with a $p$-value of 0,000 .

b8 $=$ With a significance level of $5 \%$, poverty status significantly and positively influenced the probability of individuals to migrate with a p-value of 0,000 .

b9 $=$ With a significance level of $5 \%$, the quality of health had a significant and positive effect on the probability of individuals to migrate with a p-value of 0.008 .

Meanwhile, the LR Statistics test or the F-statistic test, with a pro $>$ chi 2 value of 0.0000 , showed that, together, the independent variables influenced the probability of individuals to migrate.

\subsection{Marginal Effect in Probit}

Marginal Effect is used to see the effect of changes in a predictor variable on the response variable, assuming that the other variables are constant. In this study, the marginal effect was useful for interpreting how much influence each independent variable had on the probability of a migration decision.

Table 3: Marginal Effect in Probit

\begin{tabular}{|l|c|c|}
\hline Variable & Coefficient & Standard error \\
\hline Gender & $.0079285^{\star *}$ & .00879 \\
\hline Marital status & $.0441133^{*}$ & .01077 \\
\hline Level of education & $.0774528^{*}$ & .00385 \\
\hline Income & $.0616688^{*}$ & .00911 \\
\hline Employment status & $.0269098^{*}$ & .0119 \\
\hline Status of residence & $.0062223^{\star *}$ & .00937 \\
\hline $\begin{array}{l}\text { Agricultural Land } \\
\text { Ownership }\end{array}$ & $.0724531^{*}$ & .00922 \\
\hline Poverty Status & $.0490383^{*}$ & .00923 \\
\hline Health Quality & $.0175072^{*}$ & .00655 \\
\hline
\end{tabular}

* Significant at $\alpha=5 \%$; ** Not Significant $\alpha=5 \%$
Table 3 explains the marginal effect of the probit regression decision to migrate. Each increment of one unit of the independent variable would affect changes in the decision of individuals to migrate. Individuals who were not married, separated, divorced, widowed, and cohabited had a probability of a decision to migrate by $4.4 \%$ higher than individuals who were married. Then, increasing the level of individual education in 2014 IFLS households for one year would increase the probability of a decision to migrate by $7.7 \%$. Increasing the level of individual income in 2014 IFLS households by Rp 1,000,000/month would increase the probability of a decision to migrate by $6.1 \%$. Individuals who did not work had a probability of a decision to migrate by $2.6 \%$ higher than individuals who worked. Individuals who did not own agricultural land had a probability of a decision to migrate by $7.2 \%$ higher than individuals who owned agricultural land (Sigeze \& Balli, 2016). Poor individuals had a probability of a decision to migrate by $4.9 \%$ higher than individuals who were not poor. Increasing the quality of individual health in the 2014 IFLS household by one level (less, enough, more) would increase the probability of a decision to migrate by $1.7 \%$.

\section{Conclusion and Recommendation}

Based on the results of the research, factors that affected individual decisions to migrate in Indonesia could be known. Factors such as gender and residence status did not affect the individual's decision to migrate, meaning that the tendency of an individual to migrate was the same for both men and women. Factors such as marital status, education level, income, employment status, poverty status, land ownership, and health quality, each had a significant effect on an individual's decision to migrate.

An interesting finding from this research is that individuals who were not married, separated, divorced, widowed, and cohabitated had a greater proportion of migrants than those who were married. Besides, the income variable significantly affected the decision of individuals to migrate, indicating that individuals with an income of Rp. 0 - Rp 12,000,000 had a greater proportion to migrate compared to individuals with an income of Rp. 12,000,0001 - Rp. 40,000,000. Ownership of agricultural land significantly impacted the decision of individuals to migrate, revealing that individuals who did not have agricultural land had a greater proportion to migrate compared to individuals who had agricultural land. Also, the poverty status significantly influenced the individual's decision to migrate, implying that poor individuals had a greater proportion of migrants than non-poor individuals. Besides, health quality significantly affected individual decisions to migrate, meaning that the higher the health quality, the greater the proportion to migrate. 
This study recommends that individuals, families, communities, and policymakers need to pay attention to the factors that encourage migration and their impact on the social, economic, and sustainability aspects of economic development in Indonesia.

\section{References}

Adams, R. H., \& Page, J. (2005). Do international migration and remittances reduce poverty in developing countries? World Development, 33(10), 1645-1669. https://doi.org/10.1016/j. worlddev.2005.05.004

Adema, W., \& Ladaique, M. (2009). How expensive is the welfare state? OECD Social, Employment and Migration Working Papers, No. 92, OECD Publishing, Paris. https://doi. org/10.1787/220615515052

Barrett, A., Kahanec, M., Zimmermann, K. F., Giulietti, C., \& Guzi, M. (2013). Unemployment benefits and immigration: Evidence from the EU. International Journal of Manpower, 34(1), 24-38. https://doi.org/10.1108/01437721311319638

Burakov, D. (2017). Oil prices, economic growth and emigration: An empirical study of transmission channel. International Journal of Energy Economics and Policy, 7(1), 90-98.

Catalbas, G. K., \& Yarar, O. (2015). Determination of factors affecting internal migration in Turkey with panel data analysis. Alphanumeric Journal, 3(1), 99-117. doi: http://dx.doi. org/10.17093/aj.2015.3.1.5000113446

Devlin, C., Bolt, O., Patel, D., Harding, D., \& Hussain, I. (2014). Impacts of migration on UK native employment: An analytical review of the evidence. Occasional Paper 109, Department for Business Innovation and Skills, Home Office London.

Fasani, F., Frattini, T., \& Minale, L. (2017). The (struggle for) labour market integration of refugees: Evidence from European countries. Centre for Research and Analysis of Migration (CReAM), CReAM Discussion Paper Series 1716, Department of Economics, University College London.

Gray, C., \& Bilsborrow, R. (2013). Environmental influences on human migration in rural Ecuador. Demography, 50(4), 1217 1241. https://doi.org/10.1007/s13524-012-0192-y

Hanley, J., Ives, N., Lenet, J., Hordyk, S.-R., Walsh, C., Soltane, S. B., \& Este, D. (2019). Migrant women's health and housing insecurity: An intersectional analysis. International Journal of Migration, Health and Social Care, 15(1), 90-106. https://doi. org/10.1108/IJMHSC-05-2018-0027

Hollis, J. (2019). The psychosocial experience of UK immigration detention. International Journal of Migration, Health and Social Care, 15(1), 76-89. https://doi.org/10.1108/ IJMHSC-04-2018-0024

Hossain, M. Z. (2001). Rural-urban migration in Bangladesh: a micro-level study. Paper presented at the Brazil IUSSP conference. August.

Kerr, S. P., \& Kerr, W. R. (2011). Economic impacts of immigration: A survey. Finnish Economic Paper, 24(1), 1-32.
Kousar, R., Rais, S. I., Mansoor, A., Zaman, K., Shah, S. T. H., \& Ejaz, S. (2019). The Impact of Foreign remittances and financial development on poverty and income inequality in Pakistan: Evidence from ARDL - Bounds Testing approach. Journal of Asian Finance, Economics and Business, 6(1), 71-81. doi: http://doi.org/10.13106/jafeb.2019.vol6.no1.71

Lu, Y. (2010). Rural-urban migration and health: Evidence from longitudinal data in Indonesia. Social Science \& Medicine, 70(3), 412-419. doi: https://doi.org/10.1016/j. socscimed.2009.10.028

Lumpe, C. (2007). The labour market impact of immigration: Theory and evidence. Diskussionspapier der Forschergruppe, 1-60. doi: http://nbn-resolving.de/urn:nbn:de:bsz:352-opus-39438

Maleku, A., Kim, Y. K., \& Lee, G. (2019). Social cohesion and immigrant health: Does language-efficacy matter? International Journal of Migration, Health and Social Care, 15(1), 17-30. doi: https://doi.org/10.1108/IJMHSC-02-2018-0007

Martin, P. L., \& Zürcher, G. (2008). Managing migration: The global challenge (Vol. 63, No. 1). Washington, DC: Population Reference Bureau.

Mayda, A. M. (2010). International migration: A panel data analysis of the determinants of bilateral flows. Journal of Population Economics, 23(4), 1249-1274. https://doi.org/10.1007/s00148009-0251-x

Nguyen, H. T. T., Nguyen, C. V., \& Nguyen, C. V. (2020). The effect of economic growth and urbanization on poverty reduction in Vietnam. Journal of Asian Finance, Economics and Business, 7(7), 229-239. https://doi.org/10.13106/jafeb.2020.vol7. no7.229

Nguyen, T. T. (2020). The impact of place attractiveness and social supports on internal return migration. Journal of Asian Finance, Economics and Business, 7(5), 305-314. https://doi. org/10.13106/jafeb.2020.vol7.no5.305

Polillo, A., Kerman, N., Sylvestre, J., Lee, C. M., \& Aubry, T. (2018). The health of foreign-born homeless families living in the family shelter system. International Journal of Migration, Health and Social Care, 14(3), 260-268. https://doi.org/10.1108/ IJMHSC-11-2017-0048

Purnomo, D. (2009). The phenomenon of labor migration and its role in the development of areas of origin: an empirical study in Wonogiri district. Journal of Development Economics, 10(1), 84-102 [Indonesian].

Saptanto, S., Lindawati, L., \& Zulham, A. (2011). Analysis of migration patterns and household consumption in migration origin areas related to poverty and food vulnerability (case study of Indramayu). Journal of Organization and Management, 7(1), 21-37 [Indonesian]. http://jurnal.ut.ac.id/index.php/jom/article/ view $/ 81$

Sigeze, C., \& Balli, E. (2016). The determinants of internal migration: The case of Turkey. International Journal of Economics and Finance Studies, 8(2), 292-303.

Stańczyk-Mazanek, E., Stępniak, L., \& Kępa, U. (2019). Analysis of migration of polycyclic aromatic hydrocarbons from sewage 
sludge used for fertilization to soils, surface waters, and plants. Water, 11(6), 1270. https://doi.org/10.3390/w11061270

Tombe, T., \& Zhu, X. (2019). Trade, migration, and productivity: A quantitative analysis of China. American Economic Review, 109(5), 1843-1872. https://doi.org/10.1257/aer.20150811

Vitale, M., \& Doherty, S. T. (2018). Lifestyle and weight changes among immigrants in Canada. International Journal of Migration, Health and Social Care, 14(4), 439-454. https://doi. org/10.1108/IJMHSC-04-2018-0023

Vujicic, M., Zurn, P., Diallo, K., Adams, O., \& Dal Poz, M. R. (2004). The role of wages in the migration of health care professionals from developing countries. Human Resources for Health, 2(1), 3. https://doi.org/10.1186/1478-4491-2-3

Wood, B. M., \& Kallestrup, P. (2018). A review of non-specialised, group-based mental health and psychosocial interventions in displaced populations. International Journal of Migration, Health and Social Care, 14(3), 347-359. https://doi.org/10.1108/ IJMHSC-02-2018-0010

Yalaz, E., \& Zapata-Barrero, R. (2018). Mapping the qualitative migration research in Europe: An exploratory analysis. Qualitative Research in European Migration Studies (pp. 9-31). Switzerland: Springer. 